\title{
Muslim Albania: Kisah Islam Marginal
}

\section{Herdi Sahrasad}

Pengajar Ilmu Sosial dan Politik, Universitas Paramadina

\section{Abstract}

According to Albanian Muslim intellectual Ervin Hatibi, Albanian Muslims are not monolithic and have their own secularist traditions, so it is not only Christians who have the phenomenon of secularism like Bernard Lewis's view. Least. Albania as a small country with three Abrahamic / religious beliefs: Islam, Orthodox Christianity and Catholicism, have the opportunity to compete in virtue, where Muslims return to find their mosque, and Christians / Catholics return to find their church. The road ahead has implied a tuft hope.

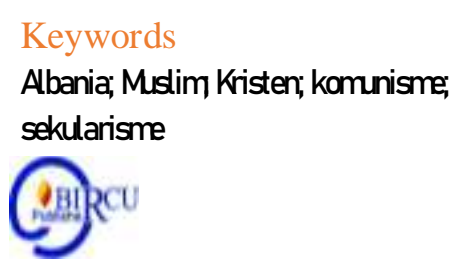

\section{Pendahuluan}

Meski terletak di Eropa, rakyat Albania memiliki persepsi bahwa mereka sudah dilupakan oleh komunitas internasional, termasuk oleh Dunia Islamdan mereka merasa sebagai negeri yang kecil, marginal dan miskin sehingga tak diperhitungkan dalam percaturan global. Namun demikian, sejumlah intelektualnya berusaha terus bersuara di forum internasional dan Organisasi Konferensi Islam (OKI) seraya mendesak OKI peduli atas nasib Muslim Albania yang umumnya terpuruk.

Pada 1980-an, para pejabat mulai mengakui bahwa kampanye melawan agama belum sepenuhnya berhasil, dan memang kontraproduktif. Sebuah studi sosiologis mengungkapkan bahwa lebih dari 95 persen kaum muda negara itu yang memilih pasangan dari latar belakang agama yang sama, sedangkan, sebelum serangan antireligius oleh rezim komunis, pernikah- an antara Muslim dan Kristen, masih merupakan hal yang tidak biasa.

Pemerintah Albania pasca komunis juga menjadi lebih sensitif terhadap rentetan kritik dari masyarakat internasional. Penerus Hoxha, Ramiz Alia, mengadopsi sikap yang relatif toleran terhadap praktik keagamaan, merujuknya sebagai "masalah pribadi dan keluarga." Warga Albania kebanyakan tetap sekuler dan tidak mempraktekkan agama mereka. Albaniamemiliki status pengamat di OKI (Organisasi Konferensi Islam), tapi sekarang Albania merupakan anggota penuh.

Konstitusi pasca komunisme memberikan kebebasan beragama bagi warganya, dan pemerintahkini mulai menghargai hak ini dalam praktek. Menurut UUD 1998, tidak ada agama resmi dan semua agama adalah sama, namun, komunitas agama yang dominan (Muslim Sunni, Bektashi, Ortodoks, dan Katolik Roma) menikmati tingkat yang lebih besar dari pengakuan resmi (misalnya, hari libur nasional) dan status sosial didasarkan pada keberadaan sejarah mereka di negara itu. Semua kelompok agama terdaftar memiliki hak untuk membuka rekening bank dan untuk memiliki properti dan bangunan. Libur resmi termasuk holydays agama dari semua empat agama dominan. 


\section{Kajian Pustaka}

\section{Muslim di Albania: Tinjauan Historis}

Di tenggara Eropa, yaitu kawasan yang dikenal dengan nama Balkan, terletak Albania. Negara ini memiliki jumlah penduduk 3,5 juta orang, 70\% penduduknya beragama Islam dan sisanya Kristen. Luas wilayah sekitar 30 ribu kilometer persegi. Negara ini di masa lampau sempat berada di bawah kekuasaan imperium-imperium besar seperti Yunani, Roma, dan Ottoman. Meskipun pada era pendudukan Romawi,kawasan Albania sempat menjadi kawasan berpeduduk Kristen, namun menyusul kemunculan Islam, terjalinlah hubungan antara bangsa Albania dengan orang-orang muslim. Dengan berimigrasinya kaum muslimin dan berdatangannya para muballig dan pedagang ke Albania, Islam secara bertahap meluas di Albania.

Penguasaan imperium Ottoman terhadap Albania mulai tahun 1430 hingga lima abad kemudian, telah membuat Islam semakin tersebar di negara itu.

Islam, setelah melalui perjalanan panjang, terpecah menjadi dua; Sunni Hanafie dan Bektashi. Keduanya menarik garis perbedaan yang tegas. Sunni Hanafie dengan tradisinya sendiri, dan Bektashi menggabungkan elemen paganisme, konsep trinitas, pengampunan dosa kepada imam, dan kultus individu Shiah. Bektashi — dengan 200 ribu pengikutnya menyebut diri sebagai Muslim toleran, namun menolak semua praktek ritual Islam; shalat lima waktu, puasa di bulan Ramadhan, dan pergi haji ke tanah suci Mekkah.

Di sisi lain, penganut Orthodox dan Katolik Roma sempat pula kehilangan tradisi ritualnya dan terperosok ke dalam masyarakat yang mengabaikan agama. Bahkan, kebanyakan menyebut dirinya atheis', dengan seluruh konotasi negatifnya.Kristen diperkenalkan Imperium Romawi pada abad ke-3. Di akhir abad ke-4, setelah perpecahan Imperium Romawi, Albania secara politik menjadi bagian Timur, atau Kekaisaran Bizantium, namun masih bergantung ke Roma.Ketika perpecahan gereja Roma dan Timur mencapai puncaknya tahun 1054, pemeluk Kristen Albania di selatan berada di bawah jurisdiksi Konstan- tinopel dan di utara berada di bawah pengawasan Roma.

Pengaturan ini bertahan sampai invasi Kekaisaran Ottoman di abad 14, dan Islam mulai diperkenalkan. Di kawasan pegunungan utara, dai Islam harus berhadapan dengan perlawanan pemeluk Katolik. Perlawanan melemah setelah para pastur yang berpengaruh memilih menghindar dan meninggalkan umatnya.Di selatan Albania, banyak pemeluk Kristen Orthodox melarikan diri ke Sicilia dan selatan Italia. Disini, tidak terjadi konversi paksa skala besar Kristen Orthodox ke Islam sampai abad 17, dan skala perang Rusia-Turki. Tekanan hanya diberlakukan pada kelompok-kelompok yang terbukti bersimpati ke gereja Orthodox Rusia. Tahun 1774, Ottoman membuat perjanjian Kuchuk-Kainarji dengan Rusia, yang salah satu pasalnya mengatakan Rusia adalah pelindung pemeluk Kristen Orthodox di dalam Kekaisaran Ottoman.

Selama bercokol di Albania, Ottoman menerapkan banyak metode efektif dalam misi Islamisasinya. Di kawasan tengah dan selatan, misalnya, menciptakan dua kelas Muslim; pashas dan bey, lengkap dengan anugerah properti skala besar dan akses politik dan ke pusat kekuasaaan.

Melalui pengaruh politik dan ekonomi inilah para pasha dan bey diharapkan mampu mengontrol petani, dan masyarakat pedesaan yang dikonversi paksa. Kepada mereka, para bangsawan 'cangkokan' Turki ini menyajikan kemakmuran ekonomi dan lainnya.

Metode lain yang digunakan Ottoman adalah dengan memanfaatkan perseteruan di antara pemimoin klan. Tahun 1385, misalnya, Sultan Murad II — penguasa Ottoman di Balkan menyanggupi permintaan Karl Thopia, penguasa Dures, untuk memerangi Keluarga Balsha. Murad II mengirim pasukannya menyusuri Via Egnatia untuk mengepung Balshas. 
Tahun-tahun berikutnya, Murad II melancarkan serangan gencar untuk menaklukan pemimpin-pemimpin klan di Balkan. Tahun 1431 ia merebut Janina dan Arta. Di penghujung 1449, Ottoman merebut pantai Ionia, sekaligus merebut semua properti dan posisi para klan untuk menjamin kesetiaan masyarakat taklukannya, Ottoman mengirim dan menyekolahkan anak-anak pemimpin klan ke Turki. Sedangkan sisa-sisa prajurit klan diintegrasikan ke dalam satu kesatuan besar di bawah komando jenderal Turki.

Metode penciptaan kelas, dan edukasi bagi anak-anak pemimpin klan, tidak sepenuhnya berhasil. Gjon Kastrioti, pemimpin klan dari Kruje, dipaksa mengirim empat anaknya ke ibukota Ottoman untuk dilatih kemiliteran. Yang termuda, Gjergy Krastioti (1403-1468), terbilang cerdas. Ia menyita perhatian sultan, yang mempercayainya memimpin ekspedisi militer ke Asia kecil dan Eropa.

Penguasa Turki makin percaya ketika Krastioti bersedia masuk Islam dan mengubah namanya menjadi Iskandar. sebagai penghargaan, sultan memberi nama Bey di belakang Iskandar.

Tidak ada keraguan lagi bagi penguasa Turki ketika menunjuk Iskandar Bey sebagai penguasa militer distrik Balkan. Ia kembali ke Albania sebagai komandan pasukan Ottoman. Namun di hari pertamanya ber- tempur dengan pemberontak Serbia, Iskandar Bey — dikenal di Albania sebagai Skanderberg —-menderita kekalahan.

Iskandar Bey membawa pasukannya melarikan diri ke Krujl. Di perjalanan ia menipu anggota pasukannya yang berasal dari etnis Turki, dan menyerahkan mereka ke benteng milik keluarga Krastioti. Di tengah keluarganya, Iskandar Bey menyatakan kembali memeluk Katolik dan mendeklarasikan perang suci melawan Ottoman. Sebagai pemimpin kharismatik, Skanderberg membangkitkan semangat perlawanan klan- klan lainnya, termasuk komunitas Yunani di Epirus. Berkekuatan 30 ribu serdadu, Skanderberg menyerang pos-pos Ottoman dan mengepung Sultan Murad II.

Perlawanan tidak nerlangsung lama. kebijakan Skanderberg membantu Raja Alfonso dari Napoli dalam perang melawan raja-raja Sisilia, menimbulkan keretakan di antara pemimpin klan. sejumlah pemimpin lokal membelot ke Ottoman, dan memerangi Skanderberg. Di Lezl tahun 1468, Skanderberg menemui ajalnya. Sultan Mehmed II pengganti Murad II, dikabarkan menangisi kematian musuh, sekaligus sahabat terbaiknya.

Kematian Skanderberg mendorong islamisasi secara menyeluruh di Albania. Untuk menjamin kelangsungan masyarakatnya, Ottoman menerapkan hukum Islam di seluruh Albania dan Balkan. Khusus pada periode ini, sejarawan H Abiva, dalam artikel Albania: Freedom Unconsidered, menulis tidak ada bukti-bukti kuat Ottoman melakukan konversi paksa terhadap penduduk taklukannya. Ini diperkuat oleh sejumlah teks sejarah yang dianalisis sejarawan Barat TW Arnold.

Menurut Abiva, konversi terjadi secara alamiahkarena Islam dianggap menawarkan praktek ritual yang tidak pelik dan rumit. Islam menempatkan pemeluknya sebagai individu yang bisa memohon kepada Allah secara langsung, atau tanpa melalui perantara petinggi agama.

Selepas abad 17, ketika koalisi pasukan Austria dan Rusia mulai melancarkan serangan ke kawasan Balkan dan Anatolia, Albania menjadi benteng terkuat Ottoman. Ini berlangsung sampai tahun-tahun awal di abad 20.

Perang Balkan (1912-1913) memaksa Ottoman mundur dari semua wilayah jajahannya di daratan Eropa, kecuali Thracia Barat di Yunani. Albania tertinggal sendirian dengan statusnya sebagai satu-satunya negara Islam di pinggir peradaban Eropa.Dalam situasi kritis, dan khawatir Albania terabsorbsi menjadi bagian negara tetangganya yang memerdekakan diri, Ismail Kemal Bey pemimpin Albania saat itu meminta kekuatan-kekuatan besar Eropa Barat menjamin 
integritas wilayah Albania. Harga yang harus dibayar masyarakat Islam Albania cukup mahal. William of Wied, pangeran Katolik, ditempatkan sebagai raja di Albania.

Selepas perang Balkan, Perang Dunia I melenyapkan harapan Albania untuk menjadi negara stabil di bawah prinsip-prinsip Islam. Tahun-tahun berikutnya, Albania menjadi jajahan Serbia, Montenegro, dan protektorat sekutu. Sementara di Turki, Kemal Ataturk memulai de-Islami-sasi dan membawa negaranya menjadi republik sekuler.

Situasi ini mendorong Ahmet Bey Zogoli menggulingkan Fan Noli Uskup Orthodox yang ditempatkan sekutu untuk memerintah Albania dan memproklamirkan diri menjadi raja. King Zog menanggalkan hukum Islamdan menggantinya dengan hukum lokal (Swiss Civil Code).

Sekularisme Zog tidak hanya disambut baik masyarakat Katolik, Orthodox, dan Bektashi, tapi menjadi lahan subur tumbuhnya komunisme di bawahAnwar Hoxha kemudian dikenal dengan nama Enver Hoxha. Perlahan tapi pasti, masyarakat Islam yang kehilangan keistimewaan warisan Ottoman mulai terserap ke dalam komunisme. Ulama kehilangan pengaruh dan gagal mengorganisir dirinya.

Akibatnya, Partai Komunis Albania (ACP) menjadi satu-satunya kelompok perlawanan terkuat untuk menghadapi Jerman. Sedangkan faksi perlawanan lainnya, Bali Kombetar yang berhaluan republik dan Legaliteti yang feodalistik, lebih suka memihak ke Jerman untuk memerangi komunisme.

Usai perang Dunia II, Albania terbebas dari Jerman, komunis di bawah Enver Hoxha mengambil alih kekuasaan. Ia segera melancarkan program penghancuran Islam secara sistematis. Seluruh ulama dan keluarga dieksekusi, tanah-tanah wakaf disita, dan seluruh masjid ditutup, dijadikan museum atau kantor Partai Komunis, atau dibongkar. Peternakan babi diperbanyak, dan Muslim dipaksa mengkonsumsinya.

Disekolah, anak-anak diminta melaporkan kepada aparat komunis jika orangtua mereka melakukan praktek ritual keagamaan, atau menyimpan Alquran. Kristen dan Bektashi mendukung semua program itu. Kedua kelompok ini meguasai setengah kursi di politbiro Partai Komunis Albania.

Namun, selepas tahun1967 stelah Enver Hoxha memproklamirkan negaranya sebagai Republik Atheis komunis mengarahkan sasarannya ke kelompok Kristen dan Bektashi. Seluruh gereja di tutup, dan kuil Bektashi dibongkar. Komunis juga membersihkan dirinya dari elemen kedua agama itu. Slogannya; agama rakyat Albania adalah Albanianisme. Kaum Muslim kehilangan masjid, sungguh pahit sebab Muslim tanpa masjid di sini akibat penindasan dan pemaksaan dari rezim komunis.

Pada tahun 1912, Albania meraih kemerdekaannya. Namun pada tahun 1945, dengan naiknya Enver Hoxha yang menganut paham komunis ke kursi kepresidenan, orang-orang Albania mengalami era pemerintahan yang represif dan mencekam. Enver Hoxha membelenggu kebebasan agama orang-orang Albania, dan bahkan sampai menghancurkan masjid- masjid di negara itu.

Setelah meninggalnya Enver Hoxha pada tahun 1985 dan melemahnya rezim komunis, kondisi di negara itu pun mengalami perubahan. Pada tahun 1990, aktivitas yayasan relijius dan masjid-masjid kembali meraih kebebasan. Pada bulan Maret tahun berikutnya, diadakan pemilu parlemen yang bebas untuk pertamakalinya. Presiden Sali Berisha adalah presiden pertama Albania pasca era komunis. Pada masa pemerintahan- nya, digalakkan usaha-usaha pembangunan kembali tempat-tempat ibadah dan perluasan hubungan dengan negara-negara muslim. Bahkan pada masa itulah Albania resmi menjadi anggota Organisasi Konferensi Islam (OKI). Namun pada tahun-tahun kemudian, perhatian pemerintah Albania terhadap Islam menjadi berkurang.

Rakyat Albania mudah menerima ajaran Islam karena selama berabad- abad mereka berada di bawah kezaliman para penguasa. Sementara itu, ajaran Islam memberi mereka 
semangat untuk melawan kezaliman. Islam adalah agama yang mengajarkan prinsip keadilan, kebebasan, dan persaudaraan. Prinsip-prinsip Islam inilah yang menarik orang-orang Albania terhadap Islam. Pada era komunis, orang-orang Albania berada di bawah tekanan dan represi, namun cahaya Islam tetap menyala di hati mereka.

Kehidupan persaudaraan antar etnis, demikian juga antara kaum muslimin dan kaum Kristen di Albania juga menarik untuk diamati. Mereka hidup berdampingan dengan rukun satu sama lain. Data pada tahun 2004 yang dikeluarkan secara bersama oleh Departemen Luar Negeri dan Pusat data statistik menunjukkan bahwa keragaman etnis dan agama di Albania masih tetap terjaga. Disebutkan bahwa etnis Albania dengan jumlah 98,6\% merupakan etnis mayoritas. Disusul dengan Yunani 1,17\%, dan etnis-etnis lainnya seperti Roma, Serbia, Montenegro Makedoni, Mesir, dan Bulgaria sebesar 0,23\%. Sementara itu, secara agama, Islam menempati posisi mayoritas yaitu $70 \%$, Kristen Orthodox $20 \%$, dan Katolik Roma $10 \%$.

Masjid selalu menjadi pusat dari kegiatan kaum muslimin karena masjid memberikan semangat dan makrifat kepada mereka. Begitu pula di Albania, masjid memiliki peranan penting dalam menumbuhkan semangat keislaman di hati kaum muslimin negara itu. Di setiap lapangan utama pada setiap kota di Albania selalu terdapat sebuah masjid. Hal ini membuktikan bahwa masjid adalah tempat yang sangat penting di mata masyarakat Albania. Sebelumn berkuasanya rezim komunis, jumlah masjid di negara itu mencapai 600 buah dan memiliki peran yang lebih aktif daripada era sekarang ini. Selama pemerintahan rezim komunis, masjid-masjid di negara itu ditutup dan sebagiannya bahkan dihancurkan. Setelah keruntuhan rezim komunis, masjid-masjid itu kembali dibangun dan sekarang ini jumlah masjid yang aktif melakukan berbagai kegiatan keagamaan mencapai 350 buah. Selain masjid, juga ada pusat-pusat kegiatan kaum muslimin lainnya, misalnya husainiyah atau yayasan- yayasan keislaman.

Pengajaran agama Islam secara formal di Albania dilakukan secara terpusat. Dengan kata lain, beberapa lembaga pengajaran tertentu di Albania memiliki tanggung jawab dalam mengajarkan agama Islam kepada para pelajar. Lembaga-lembaga pengajaran ini merupakan pengganti dari sekolah-sekolah agama yang sebelumnya melakukan kegiatan secara terpisahpisah dan tersebar di setiap masjid. Lembaga pengajaran agama terbesar berlokasi di Tirana, ibukota Albania. Di sekolah agama ini, Islam diajarkan sedemikian rupa agar terhindar dari pertentangan antar mazhab. Lulusan dari lembaga pengajaran ini memiliki peran besar dalam membangkitkan semangat keislaman kaum muslimin pada era komunis dan akibatnya banyak pula di antara mereka yang dipenjarakanoleh rezim komunis.

Sementara itu, kelompok politik atau partai-partai Islam tidak banyak berdiri di Albania. Mungkin hal ini disebabkan karena panjangnya masa pemerintahan rezim komunis yang sangat represif dan selalu menghalangi kegiatan-kegiatan politik non-komunis. Lembaga Islam terbesar di Albania saat ini,yang juga mendapatkan pengakuan resmi dari pemerintah adalah Komite Muslim Albania. Masrasah Islami Tirana adalah lembaga pengajaranyang berada di bawah Komite Muslim Albania. Di setiap kota, terdapat cabang dari komite ini dan melakukan berbagai kegiatan keislaman di kota tersebut. Selain Komite Muslim Albania, juga ada lembaga-lembaga lain, seperti Organisasi Cendekiawan Muslim, Organisasi Muslimah, atau Organisasi Pemuda Muslim Albania. Selain itu, kaum muslimin Albania juga memiliki sebuah Pusat Dialog Agama, demi menjalin persatuan dan membela hak-hak kaum muslimin di negara ini.

Meskipun Islam adalah agama mayoritas rakyat Albania dan ke-Islam-an telah menjadi jati diri mayoritas rakyat negara itu, namun perhatian yang ditunjukkan pemerintah Albania terhadap perluasan pengajaran Islam tidak memuaskan. Dalam UUD negara ini, Islam tidak disebut sebagai agama resmi negara. Bahkan, dewasa ini tampak usaha-usaha untuk 
menjadikan negara muslim ini sebagai negara sekuler. Hal ini antara lain merupakan akibat dari letak geografisnya di Eropa, yaitu di tengah negara-negara non Islam dan juga akibat dari sisa-sisa peninggalan era komunis dulu.

Dalam menghadapi situasi seperti ini, diperlukan peran aktif dari rakyat Albania sendiri agar Islam menjadi semakin berkembang dan mewarnai berbagai dimensi kehidupan masyarakat. Apalagi, masa lalu Albania yang dibawah penindasan rezim komunis telah membuat negara ini menjadi salah satu negara miskin di Eropa dan menghadapi banyak permasalahan sosial. Berpegang kembali kepada Islam secara benar adalah satu-satunya jalan untuk keluar dari kemelut itu.

\section{Pembahasan}

Kehidupan Muslim di Albania umumnya miskin dan marginal. Sejak Perang Dunia II, kaum Muslim di Albania kehilangan masjid karena mereka dijauhkan dari rumah ibadah itu oleh rezim komunis, bahkan dilarang beribadah ke masjid. Demikian halnya umat Kristen/Katolik juga dilarang ke gereja, sebab gereja dibekukan dan dikuasai oleh negara di bawah era komunisme. Para pastur dan pendeta ditindas, dibungkam sebagaimana para ulama. Dengan kata lain, Muslim kehilangan masjid, dan kaum Kristiani kehilangan gereja, itulah tragediumat-umat beragama di Albania.5

Setelah perang dunia kedua, Partai Komunis Albania (ACP) memulai penghancuran total Islam. Pada tahun 1945, semua properti wakaf dinasionalisasi dan ratusan ulama dieksekusi. Kontak Muslim Albania dengan umat Islam di Timur Tengah dan Dunia yang mayoritasnya Muslim, tidak diizinkan. Pelajaran agama untuk publik dinyatakan illegal oleh komunis.

Pukulan terakhir datang pada 6 Februari1967, ketika Albania diprokla- masikan sebagai negara atheis pertama di dunia. Semua masjid di negeri itu, total 530 masjid,dikunci dan ditutup. Mesjid yang diizinkan untuk tetap terbuka berubah menjadi museum, gimnasium dan studio bahkan gedung seni bagi para artis. Peternakan babi bermunculan di seluruh negeri dan semua wargadidorong untuk makan daging babi atau produk babi. Meskipun orang Kristen hanya sekitar 25\% dari populasi Albania, mereka merupakan lebih dari setengah dari keanggotaan politbiro Albania.

Setelah dipaksa tiarap di bawah era komunis, sholat Jumat pertama kaum Muslim baru terjadi setelah lebih dari dua puluh tahun rezim komunis melarang, dan itu baru diadakan 23 November 1990 di Tirana.Selama gelombang besar sejak 1990-anmenyusul angin perubahan yang telah melanda negara-negara Soviet dan Eropa Timur, musim semi demokrasi itu menjadi ilham bagi pembaruan di Albania, dimana Amerika Serikat dan sekutu-sekutunya telah bersemangat untuk mendorong pemilu yang bebas dan umumdi Albania pula.

Ini dukungan besar, baik dari negara maupun media Barat,yang berhasil menghancurkan komunis di Balkan, Yugoslavia dan Albania,dua negara yang memisahkan diri dari kopling Moskow pada 1950-an. Hampir setahun setelah pemberontakan populer di Eropa Timur, Yugoslavia dan Albania mulai menyerah pada teriakan internal untuk mengakhiri monopoli komunisme/Marxisme.

Selama bagian akhir dari tahun lalu, pemilihan umum yang bebas diselenggarakan di seluruh enam republik yang membentuk Yugoslavia. Hasil pemilu terbukti menjadi berkat campuran, karena meskipun mereka memberi massa yang mengatakan populer di pemerintahan, mereka juga melepaskan rasa kebencian tradisional antara berbagai kelompok etnis. Albania, sisa-sisa terakhir dari Stalinisme di Eropa, akhirnya menyerah dengan kehendak rakyatnya, tapi mengapa Albania (dan pada tingkat lebih rendah, Yugoslavia) telah menolak simpati dari Barat? 
Itu adalah sebuah pertanyaan yang perlu dijawab. Albania telah lama dicatat di Barat sebagai "Tibet dari Eropa." Wisatawan pernah mengalir ke negara itu selama era pra-komunis . Para wartawan mencatat, Albania ialahsebuah negeri dengan pegunungan terjal, sifat sangat independen dan tribalisme penduduk pedesaan, dalam keterbelakangan secara lengkap di mata Barat.

Ketika perebutan pengaruh di Balkan tercetus, menyusul runtuhnya Kekhalifahan Ottoman, kekuasaan setempat melihat bahwa negara- negara Barat telah mengizinkan Albania untuk memetakan hak mereka sendiri guna menentukan nasib sendiri. Komunis Hoxha dan Kampanye Anti-Agama.

Sebagai pemimpin beraliran Stalinis dogmatis, Enver Hoxha mengang- gap agama merupakan kekuatan memecah belah dan ia melakukan kampanye aktif terhadap lembagalembaga keagamaan,meskipunhampir tidak ada intoleransi agama dalam masyarakat Albania. Reformasi hukum Agraria dilancarkan Agustus 1945, misalnya, menasionalisasikan properti sebagian besar lembaga keagamaan, termasuk perkebunan biara, gedung pemerintah, dan keuskupan. Banyak pendeta dan tokoh agama diadili, disiksa, dan dieksekusi.6

Pada bulan Mei 1967, lembaga keagamaan telah dipaksa untuk melepas- kan semua 2.169 gereja, masjid, biara-biara, dan kuil-kuil di Albania, banyak yang diubah menjadi pusat kebudayaan bagi kaum muda. Nendori, sebuah bulanan sastra melaporkan acara tersebut dengan menyatakan kepada para pemuda hal itu dimaksudkan untuk "menciptakan negara ateis pertama di dunia."

Para ulama Islam difitnah di depan umum dan dipermalukan, jubah mereka diambil dan dirusak. Banyak Mullah Muslim dan imam Gereja Ortodoks jatuh terkulai di bawah tekanan dan para pendeta meninggal- kan "lembaga-lembaga keagamaan" masa lalu mereka.

Malah, lebih dari 200 ulama dan rohaniwandari berbagai agama yang dipenjarakan, yang lainnya terpaksa mencari pekerjaan baik dalam industri atau pertanian, dan beberapa dibunuh ataudipaksa mati kelaparan. Biara dari ordo Fransiskan di Shkoder dibakar, yang meng- akibatkan kematian empat biarawan tua. Kampanye brutal antireligius Hoxha berhasil memberantas ibadah formal, tetapi beberapa tokoh agamaIslam dan Kristen di Albania terus mempraktekkan iman mereka secara sembunyi-sembunyi, mempertaruhkan diri menghadapi hukuman berat. Individu yang tertangkap dengan Alkitab, ikon, atau benda religius lainnya menghadapi hukuman penjara yang lama. Orangtua takut untuk menyampaikan iman dan ajaran agamamereka kepada anak-anak, karena takut anak-anak mereka akan memberitahu orang lain dan takut akhirnya diciduk ke penjara.

Pejabat Komunis mencobamenjebak golongan Kristen dan Muslim selama bulan puasa atau perayaan agama lainnya seperti Prapaskah dan Ramadhan, dengan membagikan makanan. Atau aparat komunis membiarkan mereka mendistribusikan produk susu dan makanan lainnya di sekolah dan di tempat kerja, untuk kemudian mereka ditangkap dan kemudian secara terbuka, aparat rezim komunis yang biadab itumencela orang-orang tersebut. Para tokoh agamamenolak makanan dari aparat negara, dan umumnya makin ditindas. Rohaniwan yang melakukan kegiatan secara rahasia dijebloskan ke penjara.

\section{Kesimpulan}

Seperti diuraikan di atas, Albania memeluk Islam hampir secara keseluruhan, yang luar biasa bila dilihat dalam terang sejarah Albania. Asal kuno mereka adalah dari orang-orang Illyrik yang mendiami pesisir Adriatik dari semenanjung Balkan. Medan kasar dari daerah ini menjadi penghalang alami terhadap penjajah luar dan sangat memperlambat penyebaran ideide asing, seperti Kristen dan bahasanya.. Sebelum pelarangan agama pada tahun 1967, 
populasi Albania adalah 75\% Muslim, 15\% Kristen Ortodoks dan 10\% Katolik Roma. Delapan puluh lima persen dari Muslim Albaniamengikuti mzhabpemikiran Hanafi.

Mayoritas penduduk kota adalah Muslim dan sebagian besar pusat dan timur laut Albania dihuni oleh umat Islam. Setelah Kekaisaran Romawi Timur mulai runtuh jauh di Balkan, Albania diserbu oleh Negara Serbia yang memperluas wilayahnya sampai ke Napoli. Pasukan Serbia berhasil memperoleh pijakan kecil di seluruh negeri, dan untuk sementara Napoli masih mampu menguasai dan mengendalikan semua kota-kota pesisir. Setelah kematian Raja Serbia Dushan di pertengahan abad 14, pemimpin Albania Gjergj Balsha berhasil mendirikan sebuah kerajaan independen berpusat di sekitar kota utara Shkoder

Pada 1385, Ghergj Balsha tewas dalam pertempuran dengan Utsmani. Menyusul kemenangan mereka atas kekuatan gabungan dari Hongaria, Serbia, Bosnia dan Wallachians di tepi Sungai Maritza, tentara Ottoman memperluas kendali mereka atas sebagian besar wilayah selatan-tengah Balkan.

Pada 1479, seluruh negeri, kecuali untuk Durres, Dulcigno dan Antivari, berada dibawah Ottoman. Istilah lunak dari kapitulasi oleh hukum Islam memberikan Albania hak untuk mempertahankan keyakinan agama mereka. Tidak sampai awal abad ketujuh belas bahwa Islam mulai mendapatkan pegangan di Albania.

Ini adalah bukti sendiri bahwa apa yang disebut teori bahwa Islam dipaksakan Albania dan lainnya Balkan masyarakat terus tanah tidak ada dalam fakta sejarah. Islam memberi mereka jalan menuju Tuhan tanpa keterlibatan perantara dan tanpa doktrin teologis kompleks yang ditandai Kristen abad pertengahan. Islam juga memberikan Albania suara dalam administrasi tidak hanya tanah mereka sendiri, tetapi dari seluruh Negara Ottoman. Vizirs menonjol dan Pasha berasal dari Albania, dan diangkat ke pos mereka jauh sebelum mayoritas Albania mengaku Islam. Albania memproklamasikan kemerdekaannya pada 28 November 1912. Integritas wilayah Albania telah diasuransikan oleh negara-negara besar, meskipun bukan tanpa harga yang harus dibayar. Sebagai imbalan untuk perlindungan asing, seorang Kristen asing pangeran, William dari Wied, ditempatkan sebagai raja dari Albania.

\section{Daftar Pustaka}

Mark Mardell, "Is there a European Islam?”, UK time, 21 January 2008

Isa Larry Luxner, "Albania's Islamic Rebirth", contribution to Aramco World, edisi July/August 1992 print edition of Saudi Aramco World. Volume 43 no.4,

Gazmend Kapllani, "The many faces of Albanian", East European Quarterly, December 22, 1994

"Islam Albania Bangkit Setelah Masa Represi", www. al-sofwa.or.id diakses pukul 12,00 pada 2/2/2012; .Ismail Bardhi,

"Albania under the shadow of Greece", esai, www.elsie.de, 08/9/1998,

Robert Elsie, "Kosova and Albania: history, people, identity", esai, www.elsie.de, 25 February 2008 diakses pukul 22.00;

Mary Kaldor, "The Balkans- Caucasus tangle: states and citizens," esai, 9 January 2008

Isla Larry Luxner, "Albania's Islamic Rebirth", contribution to Aramco World, edisi July/August 1992 print edition of Saudi Aramco World. Volume 43 no.4;

Gazmend Kapllani, "The many faces of Albanian", East European Quarterly, December 22, 1994;

"Islam Albania Bangkit Setelah Masa Represi", www. al-sofwa.or.id diakses pukul 12,00 pada 2/2/2012. Ismail Bardhi, "Albania under the shadow of Greece", esai, www.elsie.de, 08/9/1998, diakses pukul 11.00;

Robert Elsie, Kosova and Albania: history, people, identity, esai, www.elsie.de, 25 February 2008, diakses pukul 22.00

H.Abiva, “Albania: Freedom Unconsidered”, paper, The Message International, 1991. 